\title{
Produções pedagógicas inclusivas: uma experiência formativa no curso de Geografia Licenciatura
}

\author{
Luiz Martins Junior ${ }^{1}$ \\ Rosa Elisabete Militz Wypyczynski Martins² \\ Julice Dias ${ }^{3}$
}

\begin{abstract}
Resumo: Este texto destina-se a lançar reflexões sobre a inclusão ancorada na perspectiva dos estudos culturais, cujo escopo vem buscando repensar os limites estabelecidos entre os binarismos que circunscrevem a educação há várias décadas. Sob esse viés, este texto está embasado teoricamente nos estudos pós-críticos e se ancora na vertente dos estudos culturais. Desse modo, o presente artigo tem por objetivo discutir práticas pedagógicas como possibilidades de constituição de uma cultura inclusiva com acadêmicos/as de Licenciatura em Geografia de uma universidade estadual localizada em Santa Catarina, em 2019. Participaram da construção das práticas inclusivas vinte e nove acadêmicos do curso de Geografia. Entre algumas considerações a serem ressaltadas, há de se destacar a possibilidade de desconstrução, reconstrução e ressignificação dos conceitos e pré-conceitos em torno das diferenças, da diversidade e das práticas pedagógicas inclusivas. Perante a experiência educativa de caráter inclusivo, foi possivel constatar que articular práticas diferenciadas que respeitem as diferenças e a diversidade no fazer pedagógico possibilita converter as práticas docentes conservadoras que excluem os estudantes com deficiência no espaço escolar.
\end{abstract}

Palavras-chave: Educação inclusiva. Estudos culturais. Prática pedagógica.

\section{Inclusive pedagogical productions: a formative experience in the Geography Degree course}

\begin{abstract}
This text is intended to launch reflections on inclusion anchored in the perspective of Cultural Studies, whose scope has sought to rethink the limits established between the binarisms that have

\footnotetext{
${ }^{1}$ Graduado em Geografia pela Universidade da Região de Joinville; Mestre em Geografia pela Universidade Federal de Santa Catarina; Doutor em Educação pela Universidade do Estado de Santa Catarina. E-mail: luizmartins.jr@hotmail.com ORCID iD: https://orcid.org/0000-0002-6026-8338

${ }^{2}$ Doutora em Geografia; Mestre em Educação; Professora do Departamento de Geografia da Universidade do Estado de Santa Catarina - FAED/UDESC; Docente do PPGE FAED/UDESC; Coordenadora do LEPEGEO; Coordenadora do grupo de pesquisa CNPQ - Ensino de Geografia e Diferentes Linguagens. E-mail: rosamilitzgeo@gmail.com ORCID iD: https://orcid.org/0000-0002-2875-2883

3 Doutorado em Educação/PUC/SP.; Mestrado em Educação/UNIVALI.; Graduação em Pedagogia/FURB; Docente no curso de Pedagogia da Universidade do Estado de Santa Catarina - UDESC/FAED e Docente no programa de Pós-Graduação em Educação da Universidade do Estado de Santa Catarina - UDESC/FAED. E-mail: julice.dias@hotmail.com ORCID iD: https://orcid.org/0000-0003-1896-5065
} 


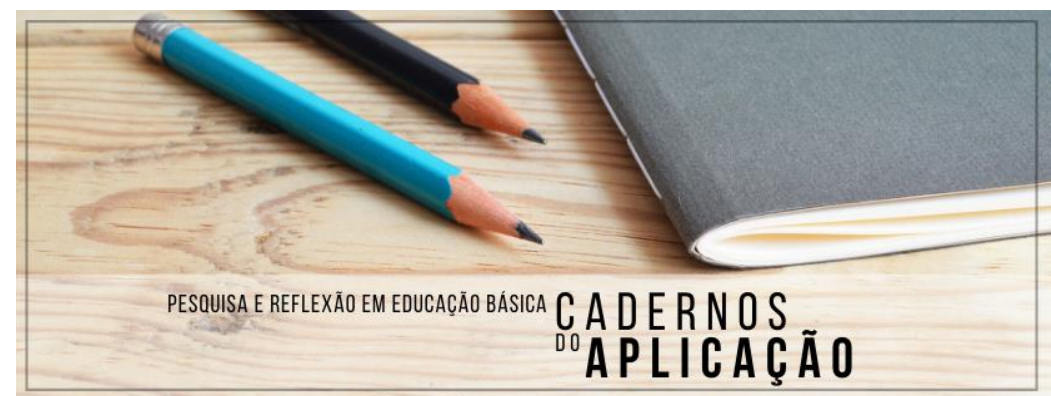

Cadernos do Aplicação

https://seer.ufrgs.br/CadernosdoAplicacao

Publicação Ahead of Print

ISSN 2595-4377 (online)

Porto Alegre | jul-dez. 2021 | v.34 | n.2

circumscribed Education for several decades. Under this bias, this text is theoretically based on postcritical studies and is anchored in the field of cultural studies. Thus, this article aims to discuss pedagogical practices as possibilities of constituting an inclusive culture with undergraduate Geography students from a state university located in Santa Catarina, in 2019. Twenty-nine academics from the Geography course participated in the construction of inclusive practices Among some considerations to be highlighted, the possibility of deconstruction, reconstruction and reframing of concepts and preconceptions around differences, diversity and inclusive pedagogical practices must be highlighted. Given the educational experience of an inclusive nature, it was possible to verify that articulating differentiated practices that respect the differences and the diversity in the pedagogical practice makes it possible to reconvert the conservative teaching practices that exclude students with disabilities in the school space.

Keywords: Inclusive education. Cultural studies. Pedagogical practice.

\title{
Producciones pedagógicas inclusivas: una experiencia formativa en el curso de Grado en Geografía
}

\begin{abstract}
Resumen: Este texto pretende lanzar reflexiones sobre la inclusión ancladas en la perspectiva de los Estudios Culturales, cuyo alcance ha buscado repensar los límites establecidos entre los binarismos que han circunscrito a la Educación durante varias décadas. Bajo este sesgo, este texto se basa teóricamente en estudios poscríticos y se ancla en el campo de los estudios culturales. Así, este artículo tiene como objetivo discutir las prácticas pedagógicas como posibilidades de constituir una cultura inclusiva con estudiantes de pregrado en Geografía de una universidad estatal ubicada en Santa Catarina, en 2019. Veintinueve académicos del curso de Geografía participaron en la construcción de prácticas inclusivas. Entre algunas consideraciones a destacar, cabe destacar la posibilidad de deconstrucción, reconstrucción y replanteamiento de conceptos y preconceptos en torno a las diferencias, la diversidad y las prácticas pedagógicas inclusivas Ante la experiencia educativa de carácter inclusivo, se encontró que articular prácticas diferenciadas que respeten las diferencias y la diversidad en la práctica pedagógica permite convertir prácticas docentes conservadoras que excluyen a los estudiantes con discapacidad en el espacio escolar.
\end{abstract}

Palabras clave: Educación inclusiva. Estudios culturales. Práctica pedagógica.

\section{Introdução: marcadores iniciais}

O ponto de partida deste artigo são os estudos partilhados pelo Laboratório de Estudos e Pesquisas de Educação em Geografia - LEPEGEO, sediado no Centro de Ciências Humanas e da Educação da Universidade do Estado de Santa Catarina - UDESC/FAED. O grupo tem ampliado seus estudos em torno de discussões que transitam por referenciais pós-críticos para 


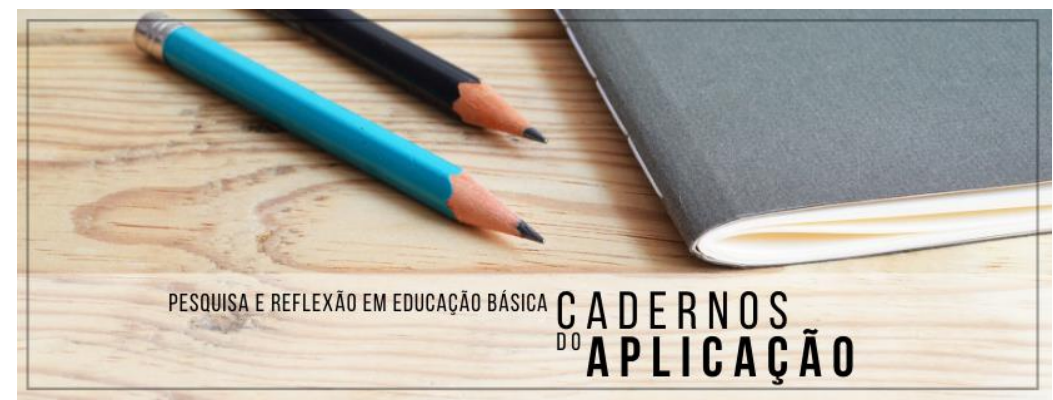

Cadernos do Aplicação https://seer.ufrgs.br/CadernosdoAplicacao

Publicação Ahead of Print

ISSN 2595-4377 (online)

Porto Alegre | jul-dez. 2021 | v.34 | n.2

dialogar com temáticas voltadas à educação básica, ao ensino de Geografia, às tecnologias digitais na educação e à formação de professores, bem como, à articulação com a educação inclusiva.

Nesse sentido, partimos de aportes teóricos pós-críticos para discutir a educação inclusiva numa perspectiva que compreenda a diversidade e a valorização da subjetividade, vivência, experiências, sentimentos, valores e princípios, que compõem a singularidade de cada um/a em diálogo com a cultura em suas mais variadas manifestações culturais, influenciada por marcadores sociais tais como classe social, etnia, gênero, religião, dentre outros.

Os pressupostos que fundamentam a educação inclusiva neste texto são tramados e bricolados $^{4}$ na crença de um processo educativo que integre todos(as) os/as estudantes, indistintamente, numa perspectiva que acolha, compreenda e inclua todas as diferenças, as particularidades, os conhecimentos diversos, as diferentes habilidades, as potencialidades, as qualidades de cada ser humano, conforme afirma Orrú (2017).

O estudo parte da seguinte problemática: "De que modo a inclusão da pessoa com deficiência, percebida como um mecanismo de busca de justiça social e igualdade de condições para todas as pessoas, pode se tornar um espaço de experiência emancipatória e democrática entre os/as estudantes no contexto escolar da educação básica?" Partindo dessa reflexão somada à concepção teórica que ancora a escrita, apresentamos uma experiência formativa com vinte e nove acadêmicos do curso de Geografia da UDESC/FAED realizada em 2019, na disciplina "Práticas Curriculares em Geografia III", tendo como foco propostas práticas para inclusão de pessoas com deficiência.

$\mathrm{O}$ artigo estrutura-se da seguinte forma: inicialmente, explora conceitos e reflexões sobre estudos culturais, discutindo brevemente seu histórico e sua inserção na pesquisa em educação no Brasil. Na sequência discute a educação inclusiva. Na terceira parte, apresenta resumidamente as etapas do processo da prática pedagógica vivenciada. Por último, destaca aspectos centrais que circunscrevem a experiência realizada com os/as estudantes de Geografia.

\footnotetext{
4 Bricolagem é um conceito caro aos Estudos Culturais. Tal conceito significa "um momento de total desterritorialização que exige a invenção de outros e novos territórios” (PARAÍSO, et.al. 2012, p. 33).
} 


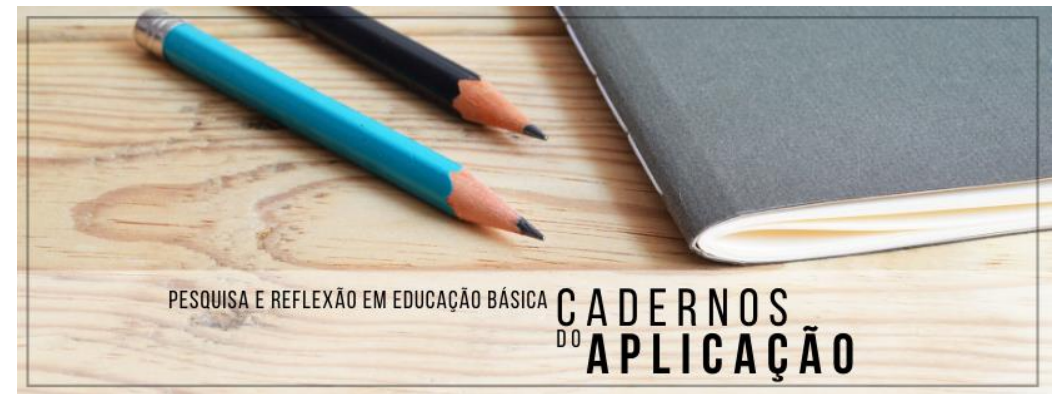

Cadernos do Aplicação https://seer.ufrgs.br/CadernosdoAplicacao

Publicação Ahead of Print

ISSN 2595-4377 (online)

Porto Alegre | jul-dez. 2021 | v.34 | n.2

\section{Aporte teórico - contornos dos estudos culturais}

Os estudos e pesquisas educacionais pós-críticas são constituídos por linhas e contornos variados que ampliaram o reconhecimento de que no mundo contemporâneo tem novas configurações culturais que influenciam na maneira de pensar e agir e afetam os modos de operar com os currículos e com as práticas escolares. Neste sentido, nos ancoramos nos estudos culturais - EC -, para explorar alguns conceitos e proposições do pensamento pós-crítico, em uma busca de dar novos sentidos para as práticas pedagógicas propostas. Nesta perspectiva, a abordagem de conceitos como cultura, inclusão e prática pedagógica, assenta-se na pressuposta vertente teórica.

Os EC surgem no século XX como um campo de estudos e pesquisas ligado a uma forma de pensar a cultura, diferentemente do que vinha sendo abordado até então, alterando a perspectiva predominante do pensamento cultural a partir das elites, entendendo-a como um bem restrito a grupos materialmente favorecidos. A superação desse modo de pensar abre espaço para entender a cultura como pertencente a todos.

Os EC emergem como um campo de resistência à imposição dos interesses dos grupos dominantes, com um forte viés político ligado aos movimentos sociais subalternos, que buscavam visibilidade e protagonismo. Essa abordagem alcança reconhecimento nos anos 1960, na Inglaterra, a partir de três textos publicados na década anterior, identificados como fontes dos EC, tendo como autores: Hoggart, Williams e Thompson (ESCOSTEGUY, 1998). A autora ressalta que o surgimento dos EC está ligado a dois pontos de vista - o político e o teórico:

[...] do ponto de vista político, é sinônimo de "correção política", podendo ser identificado como a política cultural dos vários movimentos sociais da época de seu surgimento. Da perspectiva teórica, resultam da insatisfação com os limites de algumas disciplinas, propondo, então, a interdisciplinaridade [...] (ESCOSTEGUY, 1998, p. 88).

Embora a origem histórica dos EC remeta à década de 1960, Dalmonte (2001) aponta que em meados do século anterior, com a Revolução Industrial, têm início mudanças gradativas na concepção e democratização da arte, integrando o processo de desenvolvimento dos EC. Segundo o autor, os meios de comunicação de massa e outras produções industriais 


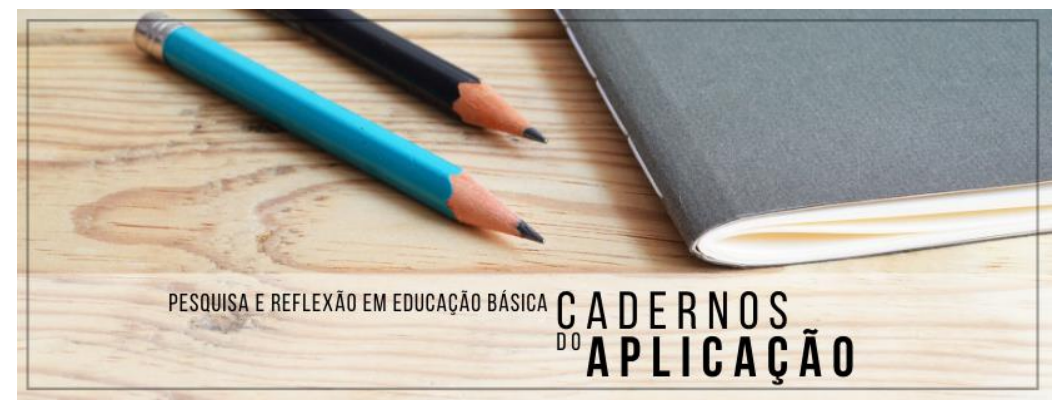

Cadernos do Aplicação https://seer.ufrgs.br/CadernosdoAplicacao

Publicação Ahead of Print

ISSN 2595-4377 (online)

Porto Alegre | jul-dez. 2021 | v.34 | n.2

contribuíram para popularizar a arte e a informação, desse modo, a cultura gradativamente foi se tornando mercadoria.

Escosteguy (1998) situa que é a partir dos três autores pioneiros dos EC que se altera a ideia de cultura, fundamental para a compreensão desse novo campo de pesquisa: "Para Williams e Thompson, cultura era uma rede vivida de práticas e relações que constituíam a vida cotidiana dentro da qual o papel do indivíduo estava em primeiro plano" (ESCOSTEGUY, 1998, p. 89). Dito de outro modo, a concepção de cultura global de Williams sustenta-se na ideia de que todos os sujeitos, de todas as esferas sociais e econômicas, possuem cultura, sem níveis de hierarquia entre elas. Mais do que isso, a cultura passa a ser objeto complexo de estudos, afinal, não é mais algo estático, todavia, dinâmico, que carrega sua historicidade, portanto, é cotidianamente reconstruída, reinventada e ressignificada.

Escosteguy (1998) afirma que a proposta original dos EC é considerada teoricamente mais política do que propriamente analítica. Embora se sustente em um marco teórico específico, amparado pelo Marxismo, a história desse campo está entrelaçada com os movimentos sociais da época. Esse campo de estudos ganhou repercussão em diferentes contextos, por não se limitar a estabelecer fronteiras teóricas, políticas e sociais à concepção de cultura, de identidade e de diferença.

Os EC adentraram no Brasil, no campo da educação, na última década do século XX. Um dos marcos dessa entrada circunscreve-se nas discussões sobre currículo, inicialmente no Programa de Pós-Graduação em Educação da Universidade Federal do Rio Grande do Sul UFRGS:

[...] um dos acontecimentos decisivos para o estabelecimento de algumas das vinculações que hoje temos entre EC e Educação teve lugar no final de 1996, quando, na reestruturação do Programa de Pós-Graduação em Educação da UFRGS, foram introduzidas linhas de pesquisa, em substituição às anteriores áreas de concentração, entre as quais a linha 'Estudos Culturais em Educação' [...] (WORTMANN, COSTA, SILVEIRA, 2015, p.33).

De acordo com Escosteguy (1998), a partir da década de 1970 os EC transformaram-se em uma força motriz de viés intelectual de esquerda. O movimento intelectual representou um impulso teórico e político para além da universidade, pois, na Inglaterra, se constituiu por questões de resistência política e compromisso com mudanças sociais. Stuart Hall (1997) aborda conceitualmente a cultura, levando em conta “[...] a enorme expansão de tudo que está 


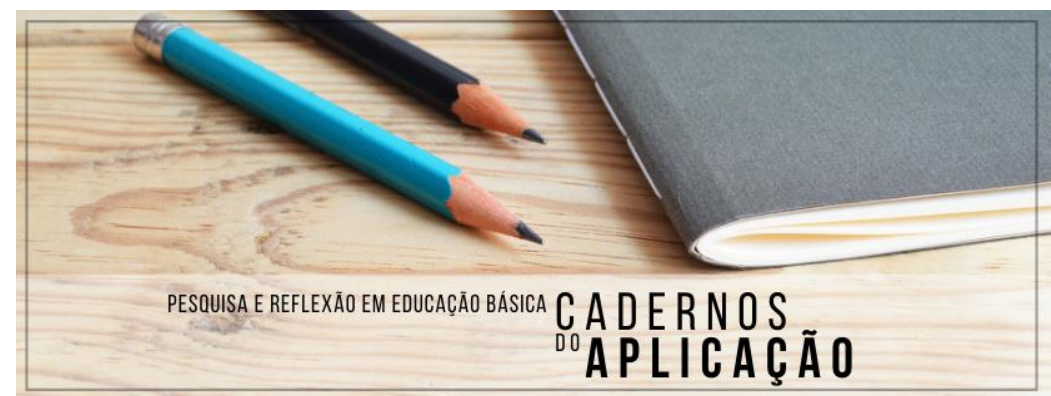

Cadernos do Aplicação https://seer.ufrgs.br/CadernosdoAplicacao

Publicação Ahead of Print

ISSN 2595-4377 (online)

Porto Alegre | jul-dez. 2021 | v.34 | n.2

associado a ela, na segunda metade do século XX, e o seu papel constitutivo, hoje, em todos os aspectos da vida social" (ESCOSTEGUY, 1998, p. 01). A linguagem, a literatura, a arte, a filosofia, os sistemas de crenças morais e religiosas por algum tempo constituíram aquilo que se considerava ser a cultura, mas, contemporaneamente, com os EC, amplia-se e remodela-se essa ideia.

Nesse contexto, é fundamental estabelecer um paralelo da cultura em sua esfera substantiva, material, no tempo de fluidez informacional, de transações e conexões globais instantâneas em decorrência das tecnologias digitais. Segundo Hall (1997), a segunda metade do século XX (e o que viria acontecer no novo milênio) atribui uma importância ímpar à cultura: "Os meios de produção, circulação e troca cultural, em particular, têm se expandido, através das tecnologias e da revolução da informação" (HALL, 1997, p. 02). De acordo com esse autor, em outros momentos históricos não houve revolução que se possa equiparar aos produtos culturais e mudanças estabelecidas nos últimos tempos, afinal, “[...] a importância das revoluções culturais do final deste século XX reside em sua escala e escopo globais, em sua amplitude de impacto, em seu caráter democrático e popular” (HALL, 1997, p. 02).

Hall (1997) entende que há uma teia a enredar culturas, porque uma sociedade tão plural, diversa e heterogênea está em uma rede na qual nada foge de conexões. Por isso, pode-se afirmar que a cultura é uma instância dinâmica, sem fronteiras, construída e desconstruída de modo constante. Conforme entende Hall,

[...] por bem ou por mal, a cultura é agora um dos elementos mais dinâmicos - e mais imprevisíveis - da mudança histórica no novo milênio. Não deve nos surpreender, então, que as lutas pelo poder sejam, crescentemente, simbólicas e discursivas, ao invés de tomar, simplesmente, uma forma física e compulsiva [...] (HALL, 1997, p. 04).

Nesse sentido, acreditamos que é fundamental a valorização das diferentes manifestações culturais, no sentido de reconhecer a origem e o contexto cultural em que cada sujeito exerce agência. Não há cultura que padronize as infinitas possibilidades de ser no mundo. Não há cultura herdada historicamente que não seja possível de ser desconstruída e reconstruída. As culturas compõem a diversidade, não havendo uma que seja símbolo ou arquétipo da diversidade cultural, pois isso significaria confrontá-la a algum nível de hierarquização cultural. A diferença consiste, portanto, no processo de construção cultural 


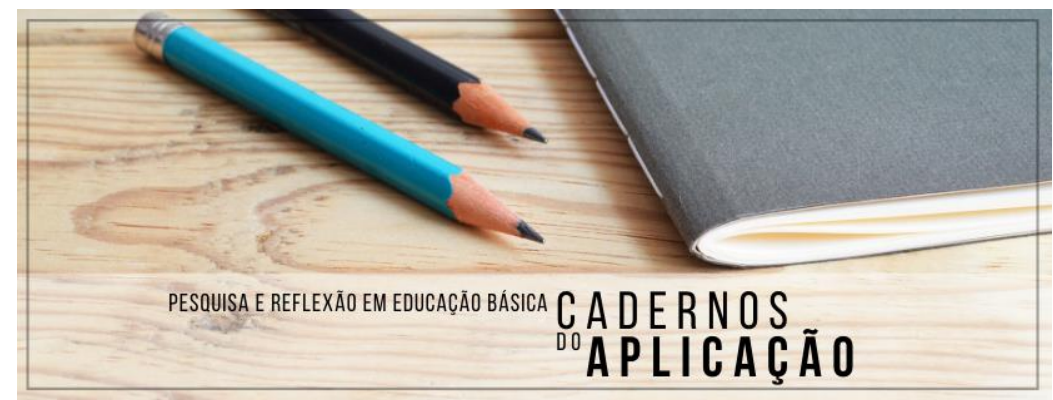

Cadernos do Aplicação https://seer.ufrgs.br/CadernosdoAplicacao

Publicação Ahead of Print

ISSN 2595-4377 (online)

Porto Alegre | jul-dez. 2021 | v.34 | n.2

constitutivo de nosso próprio processo de humanização e desenvolvimento social e cultural do que aprendemos a chamar de sociedade (DIAS, 2009).

Segundo Felipe e França (2014), a diversidade biológica é um produto da natureza, mas o mesmo não se pode dizer sobre a diversidade cultural, que não é um ponto de origem, todavia, um processo forjado pelas relações de poder que fazem parte da sociedade. Esse fluxo de forças centrípetas e centrífugas, por sua vez, estabelece o outro diferente do "eu" e o "eu" diferente do outro como uma forma de exclusão e marginalização. É nessa teia relacional que se insere a educação inclusiva.

\section{Considerações sobre a educação inclusiva}

Para os EC, a educação inclusiva parte do princípio do outro que convive com o diferente, tanto no macro espaço, que é a sociedade, quanto na sala de aula, um micro espaço do sistema. O conceito de "diferença" está estreitamente associado à heterogeneidade de classe, gênero, religião, etnia, com algum tipo de deficiência, que por sua vez produz diferentes subjetividades, discursos, significados, identidades e características de natureza física, intelectual e sensorial.

Silva (2015) filia o conceito de diferença a um processo discursivo e linguístico, desprendido daquilo que é uno. Significa, então, que diferença não é um processo natural ou biológico, mas consiste em atos de criações culturais e invenções sociais formados a partir de intrincados processos subjetivos, que se originam e se amalgamam em relações de poder entre os sujeitos em determinado espaço e tempo. Silva (2000) considera que a linguagem e o discurso são comumente dispositivos que permitem nomear e dar sentido às questões do contexto vivido, o que ainda implica nas possibilidades de explicar a própria existência e as formas de como se aprende a lidar com tudo o que cerca os seres humanos cotidianamente.

Orrú (2017, p. 129) explora o conceito de diferença, situando-a como "aquilo que é diferente”, ou seja, “[...] nela há ausência de semelhança, há desconformidade, divergência”. Em outras palavras, “[...] contém a própria diversidade, ela é inexata e, ao mesmo tempo, é excesso de uma grandeza, nela não há repetição”. Em contraste com essas pontuações, VeigaNeto (2004) define a diferença como característica inerente à vida em sociedade, ou seja, a 


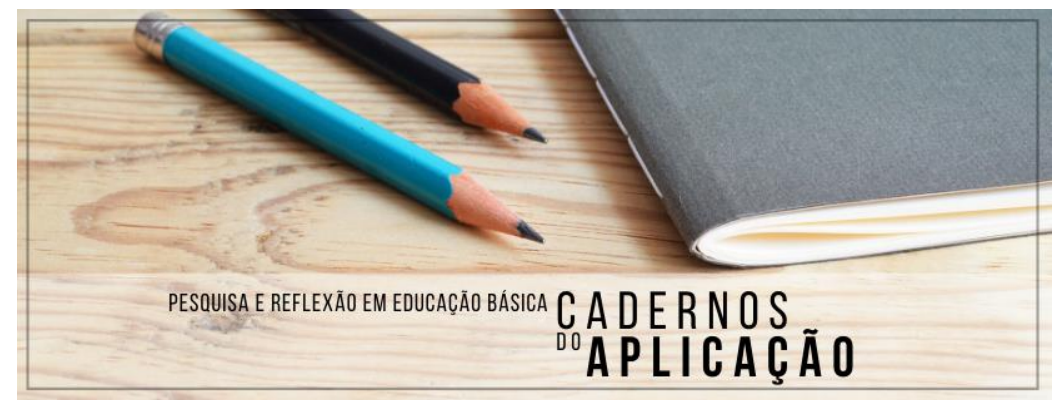

Cadernos do Aplicação https://seer.ufrgs.br/CadernosdoAplicacao

Publicação Ahead of Print

ISSN 2595-4377 (online)

Porto Alegre | jul-dez. 2021 | v.34 | n.2

diferença está no mundo como parte constitutiva do próprio sujeito. A partir desse conjunto de definições, pode-se dizer que a diferença não pode se constituir como critério de hierarquização da qualidade humana, pois, independentemente da condição material de cada um, todos são indivíduos de uma mesma estrutura social, com o mesmo valor existencial. Entretanto, “[...] o que se deve considerar é a diferença na totalidade e a totalidade na diferença, sem se prender à prejudicial polarização do normal (igual), de um lado, e do diferente (desigual), do outro" (MARQUES; MARQUES, 2003, p. 234).

A polarização citada por Marques (2003) diz respeito aos binarismos, ou seja, estabelecimento de oposições e descarte do complexo sistema que os une. De acordo com a perspectiva dos EC, pode-se ressaltar a importância e emergência da reflexão sobre tal prática e perpetuação pedagógica das polarizações e binarismos, sobretudo, no âmbito da inclusão escolar. A interface entre diferença, inclusão e os EC permite pensar a diferença entre sujeitos enquanto fenômeno humano, como processo de ser e existir, reproduzindo e produzindo cultura. O diagnóstico da diferença, seja ela qual for, restringe, limita. O reconhecimento dela como fenômeno humano e produção cultural liberta e permite ao sujeito ser, aprender e se desenvolver nas infinitas possibilidades de nossa existência. No que diz respeito ao conceito de inclusão, Lopes e Fabris (2016) destacam que no dicionário Houaiss a palavra inclusão contempla quatro acepções pontuais, sendo elas:

[...] 1- verbo: encerrar, pôr dentro de; fazer constar de; juntar (-se); inserir (se), introduzir (-se). 2- fazer figurar ou fazer parte de certo grupo, certa categoria de pessoas; pôr. 3- conter em si; compreender, conter, abranger. 4 trazer em si; dar origem a; implicar, envolver, impor [...] (LOPES; FABRIS, 2016, p. 68).

As autoras justificam que a lógica imperativa desse conjunto de significados está amplamente sustentada no princípio universal das condições de acesso e do direito de todos/as à vida social, cultural e educacional, isto é, todos num mesmo espaço e tempo usufruindo dos mesmos direitos humanos, sociais, culturais e convivendo com alteridade e diferenças (LOPES; FABRIS 2016). Considerando os significados apontados, o conceito de inclusão pensado por pesquisadores dos EC significa, 


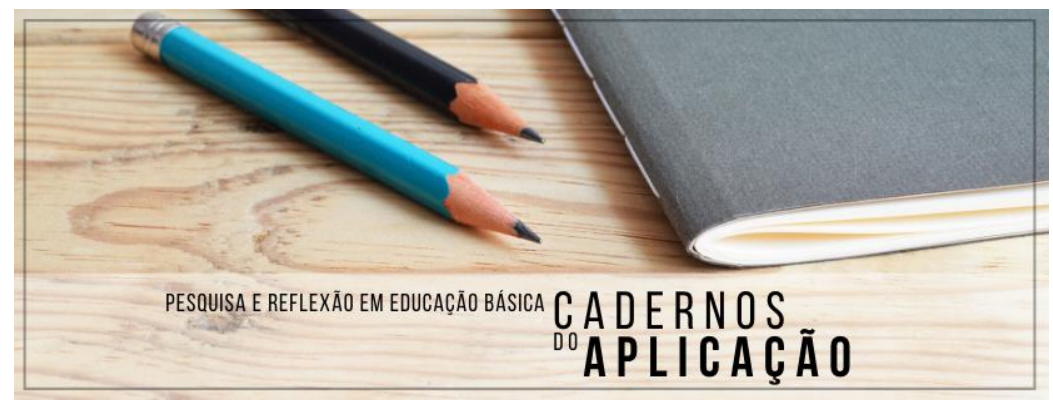

Cadernos do Aplicação

https://seer.ufrgs.br/CadernosdoAplicacao

Publicação Ahead of Print

ISSN 2595-4377 (online)

Porto Alegre | jul-dez. 2021 | v.34 | n.2

[...] uma coisa de supervivente, de resiliente, de resistente. De quem sobrevive a situações extremas, mas principalmente que sobrevive a um "outro". Um supervivente luta contra maré, ao que é inóspito, ao que é repulsivo, ao que lhe parece usurpador da vida. A inclusão, portanto, é uma experiência vital, de vida, de auto fortalecimento, de capital relevância. [...] inclusão é um conjunto de ideias e de ações que se combinam e produzem a materialização do ato consumado sem exceções, discriminações ou esquivos, isto é, a materialização da mais genuína humanização [...] (ORRÚ, 2017, p. 68-69).

A inclusão pressupõe uma conexão entre ação e reação, isto é, entender o outro com o olhar dele e com as suas diferenças, versatilidades e diversidade. Trata-se, então, da condição de vida que é atribuída ao sujeito, sendo essa determinada pelo viés cultural, subjetivo e humano, ou dito de outro modo, de ser e estar no mundo e construir outras formas de significação e sentidos culturais. Dessa maneira, a inclusão nessa direção está intimamente ligada às possibilidades de um processo de recriação, reinvenção do mundo, das atitudes do ser humano e das políticas educacionais que afetam e são afetadas pela unidade escolar.

Essa compreensão, por sua vez, estabelece o paradigma da inclusão como um par dialético que se junta ao paradigma cultural enquanto construção social e de significação do outro. Isso nos remete a compreender que as experiências culturais contribuem sobremaneira para romper com a invisibilidade das diferenças.

Todo esse processo de mudança social e cultural está conectado com aquilo que VeigaNeto e Lopes (2011, p. 127) afirmam como um "mundo isotrópico", ou seja, um espaço geográfico onde "[...] todas as propriedades se manifestam da mesma maneira e intensidade, em todas as direções e independentemente de onde o observamos". Levando-se em conta esse contexto, Orrú (2017) discute que o paradigma da inclusão na contemporaneidade provoca rachaduras, mudanças, movimentos, enfoques, atitudes e possibilidades de desnaturalizar e desconstruir os espaços homogêneos que têm sido preconizados pelas leis, políticas e diretrizes equalizadoras, reguladoras e patológicas ${ }^{5}$, ou seja, como algo determinado de cima para baixo, sem considerar as condições subjetivas, discursivas, identitárias e culturais dos sujeitos. Em diálogo com a autora, Veiga-Neto $(2005$, p. 4) chama atenção para o fato de que uma vez

\footnotetext{
${ }^{5}$ Orrú (2017) explica que as políticas de classificação biomédica são um instrumento dispositivo balizador para determinar quem é normal e anormal.
} 
inventado o espaço equalizador, regulador e segregador, “[...] agora tem que desinventar, e inventar a inclusão".

Conceber a inclusão na contemporaneidade requer estranhamento e criticidade perante as práticas e políticas deterministas que são desejadas para aqueles que são excluídos. Nesse sentido, a inclusão consiste em "[...] restaurar a ordem natural perdida, isto é, voltar ao estado original que seria do próprio mundo e, bem por isso, da própria natureza dos seres humanos" (VEIGA-NETO; LOPES, 2011, p. 128). Esse processo de inclusão parte da construção cultural que se dá a partir dos saberes e fazeres cotidianos, ora pelos ensinamentos familiares, ora pelo trabalho escolar, ora pelas redes relacionais que engendram mentalidades e comportamentos.

Nesse sentido, Veiga-Neto (2004) ressalta que muito se tem deparado com discursos que argumentam que a escola com um ensino excelente é competente e capaz de efetuar a inclusão de todos/as no cotidiano escolar. No entanto, o autor argumenta que a inclusão não pode se fundamentar apenas em discursos pedagógicos, todavia, precisa estar amplamente amparada num trabalho colaborativo, emancipatório, dialético, humanístico e de acolhimento, como tradução cultural ${ }^{6}$.

O conceito de inclusão remete a práticas que vão para além dos muros da escola, aproximando toda a cultura escolar, reconhecendo os sujeitos que dela fazem parte, reinventando o cotidiano escolar e as relações que o engendram a partir dos diferentes contextos onde os estudantes se inserem. Essa perspectiva de inclusão, por sua vez, se constitui nas possibilidades de um processo educativo que acolha a todos/as independentemente de suas diferenças e singularidades.

Sendo assim, por inclusão entende-se um movimento pendular de presença de sujeitos e atos de ressignificação do universo escolar, que põe em diálogo valores e princípios, e no reconhecimento do outro frente àquilo que lhe é imposto, ou aceito como único, decorrente do que o sujeito vivencia em suas condições materiais de existência. Em suma, essas mudanças precisam ser consolidadas com o único propósito de estabelecer um contexto escolar que, segundo Camacho (2003), seja capaz de acolher e cultivar as diferenças como um elemento de valor positivo. Consiste também na abertura de um espaço plural e multicultural, no qual

\footnotetext{
${ }^{6}$ Esse conceito de Veiga-Neto (2004, p. 51), inspirado em Peter Maclaren, significa "[...] a escola como um ambiente de tradução entre culturas, um espaço de tradução entre experiências culturais e formas de vidas diferentes".
} 


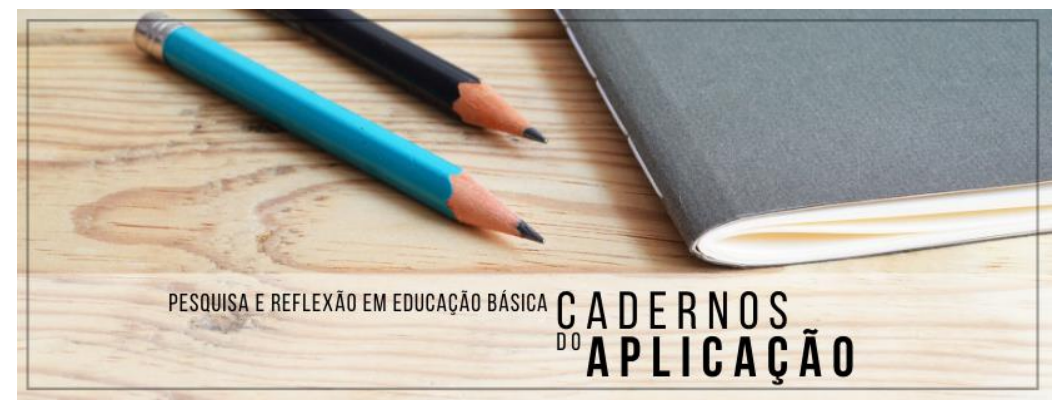

Cadernos do Aplicação

https://seer.ufrgs.br/CadernosdoAplicacao

Publicação Ahead of Print

ISSN 2595-4377 (online)

Porto Alegre | jul-dez. 2021 | v.34 | n.2

interajam as cores, os gêneros e as modalidades de aprendizagem, permitindo, assim, acesso a todos/as aos bens culturais produzidos historicamente pela humanidade. Todavia, essas mudanças partem também da compreensão da função social do professor como mediador, interventor pedagógico, artífice ${ }^{7}$ e humanizador no contexto escolar da educação básica. Para tanto, a seguir apresentamos a proposta inclusiva vivenciada no contexto de uma universidade pública catarinense.

\section{Desenho e contexto da proposta inclusiva}

Nesta parte trazemos exemplos de propostas pedagógicas que trabalham na perspectiva não somente da inclusão, mas também de práticas que possam auxiliar o/a professor/a de Geografia a realizar um ensino que busque por justiça social e igualdade de condições para todos/as. As atividades desenvolvidas foram elaboradas com os/as acadêmicos do curso de Geografia de UDESC/FAED em 2019 na disciplina "Práticas Curriculares em Geografia III".

Os encontros formativos objetivaram integrar conceitos científicos às propostas inclusivas no curso de Geografia. Vinte e nove acadêmicos/as participaram das quatro etapas que compuseram esta experiência, sendo treze deles autodeclarados do sexo masculino e dezesseis do sexo feminino, com idades entre dezoito e quarenta anos. Os acadêmicos foram divididos em oito grupos, e, por meio de sorteio, cada grupo ficou responsável por organizar uma oficina voltada para uma deficiência, utilizando conceitos e conteúdos geográficos.

$\mathrm{Na}$ primeira etapa foi realizado um momento expositivo, com informações sobre deficiência, tipos de deficiência e legislação concernente à inclusão. Em seguida à explanação, foi aberto espaço para uma conversa com os/as acadêmicos/as para sanar dúvidas e troca de informações a respeito da temática, juntamente com relatos pessoais de vivências familiares com a deficiência.

A segunda etapa consistiu na proposta de formação de grupos com quatro integrantes para desenvolver uma atividade de caráter inclusivo a partir de um conteúdo da Geografia escolar. Após a formação dos grupos, foi sorteado um tipo de deficiência e um conteúdo da

\footnotetext{
${ }^{7}$ Esse termo trata de uma relação dialética do trabalho do professor em sua ação pedagógica, ou seja, o professor é artífice no seu trabalho artesanalmente reflexivo, reflexivamente artesanal (KAERCHER, 2016, p. 211).
} 
Geografia, constitutivo da matriz curricular do sexto ao nono ano dos anos finais do ensino fundamental, conforme ilustrado no quadro 1.

\section{Quadro 1 - Configuração e divisão das equipes envolvidas}

\begin{tabular}{|c|c|c|c|}
\hline Grupo & Deficiência & Temática da Geografia & Ensino Fundamental \\
\hline Grupo 1 & Intelectual & Oceania & 7 ano \\
\hline Grupo 2 & Visual & População & 7 ano \\
\hline Grupo 3 & Visual & Estrutura da terra & 6 ano \\
\hline Grupo 4 & Visual & Cartografia escolar & 8 ano \\
\hline Grupo 5 & Visual & Formas de Relevo & 7 ano \\
\hline Grupo 6 & Auditiva & Regiões Brasileira & 8 ano \\
\hline Grupo 7 & Auditiva & Clima e Temperatura & 6 ano \\
\hline Grupo 8 & Física & Lugar e Paisagem & \\
\hline
\end{tabular}

Fonte: Elaborado pelos autores.

Em seguida, foi solicitado aos grupos que elaborassem atividades, tendo como exemplo um jogo de tabuleiro (Figura 1), que envolvessem uma das seguintes deficiências: intelectual, visual, auditiva ou física, explorando a deficiência e o conteúdo sorteado.

Figura 1 - Sugestão de jogo pedagógico

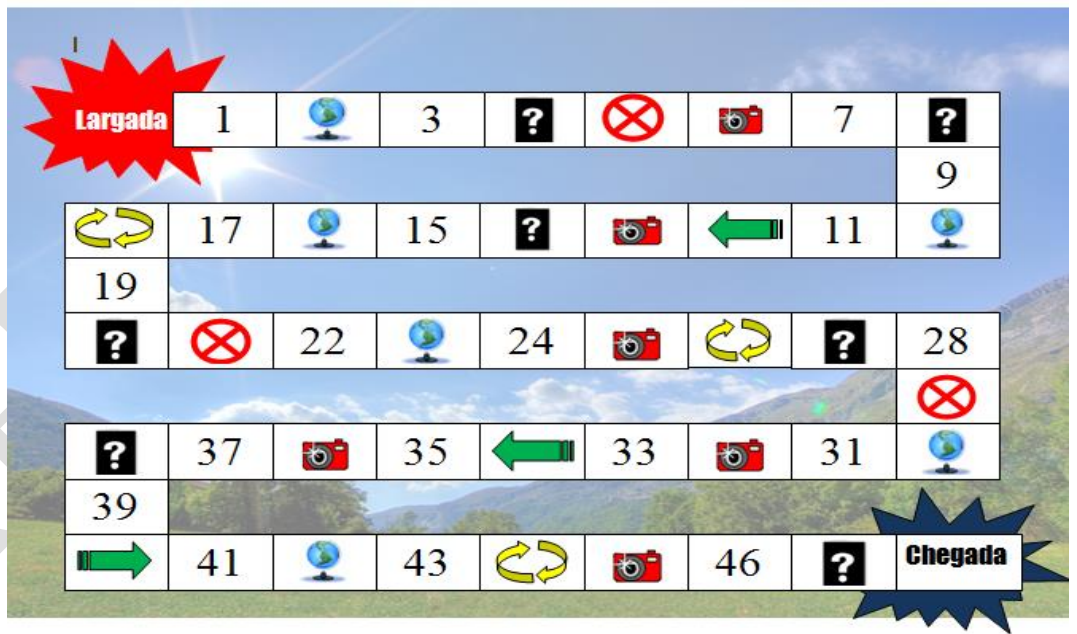

Fonte: Elaborada pelos autores.

Após a discussão sobre qual atividade seria realizada, tendo em vista o sorteio da deficiência, do conteúdo e do ano escolar, cada grupo foi orientado a elaborar um plano de aula destacando os objetivos, as etapas e os materiais utilizados na organização da prática pedagógica. Foi uma etapa importante para planejamento e escolha dos materiais, o jogo que 


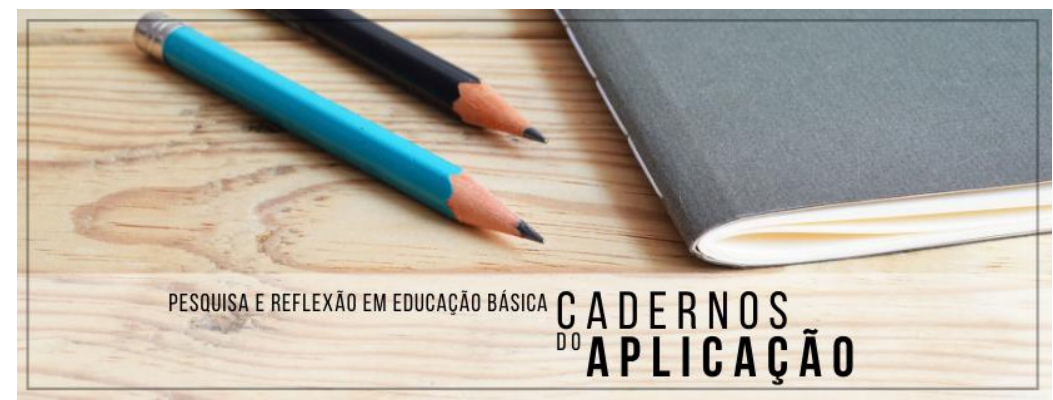

Cadernos do Aplicação

https://seer.ufrgs.br/CadernosdoAplicacao

Publicação Ahead of Print

ISSN 2595-4377 (online)

Porto Alegre | jul-dez. 2021 | v.34 | n.2

seria elaborado, quais conceitos estruturantes da Geografia articulados à temática central, as regras do jogo e, principalmente, como seria a participação dos/as estudantes no desenvolvimento da oficina no sentido de não deixar de fora o/a estudante com deficiência. Isso porque, em sala de aula, geralmente, quando são propostos jogos que envolvam competição, muitos dos estudantes com deficiência são deixados de lado. Para o desenvolvimento dessa etapa foram destinadas quatro aulas, considerando o tempo necessário para a discussão, a estruturação e a materialização da atividade.

A terceira etapa consistiu na socialização das atividades, sendo que cada grupo teve um tempo para expor o que desenvolveu, para explanar as regras do jogo, o tipo de deficiência abordada, os conteúdos e conceitos geográficos escolhidos, bem como, um tempo para a simulação do jogo com os colegas de sala de aula.

Por fim, na quarta etapa, foi realizada uma avaliação descritiva da prática desenvolvida, com questões referentes à dinâmica da atividade proposta, aos conteúdos abordados, às possibilidades inclusivas e em que essa proposta contribuiu para a formação dos/das acadêmicos/as. Sendo assim, na sequência, discutimos as produções dos acadêmicos durante a proposta executada.

\section{Produções dos acadêmicos do curso de Geografia: pensando na educação inclusiva}

De um universo de oito trabalhos desenvolvidos pelos/as acadêmicos, trouxemos aqui nesta parte três trabalhos, destacando o tipo de deficiência, o conteúdo curricular, os materiais utilizados e as possibilidades metodológicas. A Equipe 1 desenvolveu o jogo pedagógico "Roleta Populacional", conforme a Figura 2, seguindo a lógica de um tabuleiro tradicional. A proposta foi mapeada e construída a partir da deficiência intelectual e envolveu o conteúdo “população e suas interfaces”, que pode ser trabalhado com o nono ano do ensino fundamental. A atividade teve por objetivo problematizar a questão da dinâmica populacional, relação entre o aumento do número de habitantes e o nível de desenvolvimento de um dado território. 


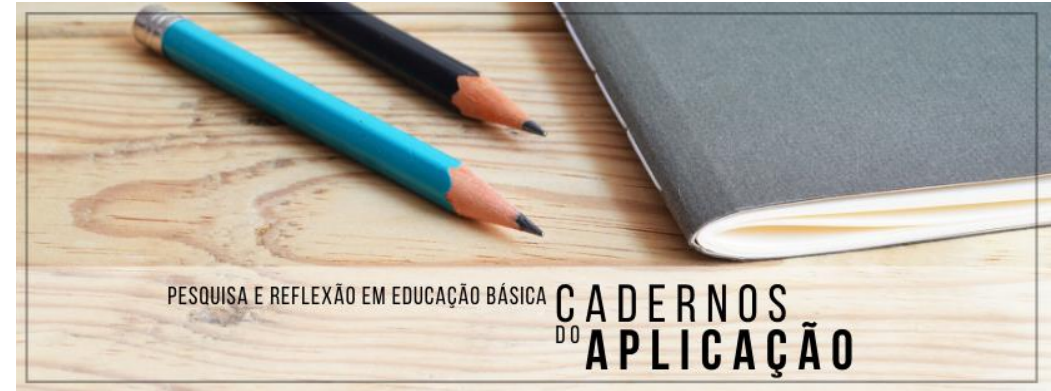

Cadernos do Aplicação https://seer.ufrgs.br/CadernosdoAplicacao

Publicação Ahead of Print

ISSN 2595-4377 (online)

Porto Alegre | jul-dez. 2021 | v.34 | n.2

Figura 2 - Roleta Populacional

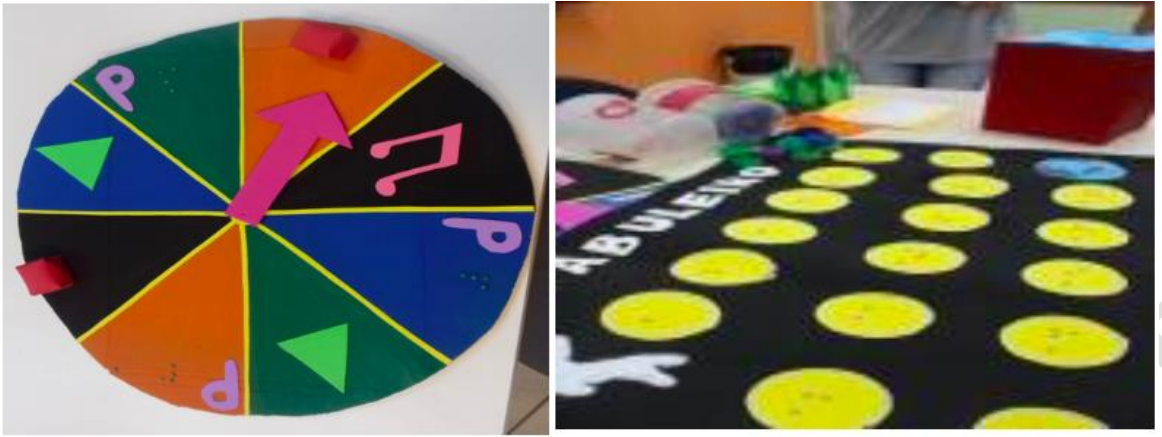

Fonte: Acadêmicos da Licenciatura em Geografia (2019).

A "Roleta Populacional" foi elaborada com os seguintes materiais: tampinhas de garrafa, dois potes plásticos, papelão, tinta colorida, cola, tesoura e E.V.A. Metodologicamente, o jogo se inicia na divisão de 3 grupos, que pode ser feita pelo/a professor/a por meio de sorteio. Cada participante do grupo tem uma chance de jogar cada rodada para que todos possam participar.

Estruturalmente, o tabuleiro é composto por 18 casas, sendo que, para avançar qualquer casa é necessário rodar a roleta, realizando a atividade proposta para cada "espaço". Se o grupo errar, continua na casa em que está. Caso acerte, avança no tabuleiro. O símbolo caracterizado pela letra $\mathbf{P}$ remete à resolução de questões sobre população que deve ser feita pelo grupo. Assim, os integrantes devem responder uma pergunta pré-definida pela/o professora/o e a escolha da pergunta será feita por meio de sorteio. Sorteada a pergunta, o professor deverá ler em voz alta e com calma, para entendimento da questão. Resolvendo corretamente o desafio, o grupo pode avançar uma casa.

O símbolo da nota musical, denominado música, está ligado à identificação de uma música relacionada à cultura que preenche o quadro populacional brasileiro. Na resolução do desafio, o/a estudante deve escutar uma música, pré-definida pela/o professora/o, identificando que manifestação cultural está sendo representada. Se a resposta for correta, o grupo avança três casas. Se a roleta cair no símbolo caixa, o/a estudante deve colocar a mão em uma caixa surpresa, dentro da qual estarão objetos que representam os grupos que formaram a população brasileira (indígenas, negros, brancos). A equipe responsável por essa resposta deve identificar que grupo étnico o objeto surpresa representa, usando o tato. Se o objeto for corretamente identificado com a cultura à qual pertence, avança uma casa. 
Cadernos do Aplicação

https://seer.ufrgs.br/CadernosdoAplicacao

Publicação Ahead of Print

ISSN 2595-4377 (online)

PESQUisa e REFLEXão em EdUCAÇão básica C A DE R N OS

${ }^{\circ}$ APLICAÇÃO

Porto Alegre | jul-dez. 2021 | v.34 | n.2

O símbolo triângulo consiste no desafio de construir uma pirâmide etária, podendo ser em âmbito municipal, estadual ou nacional, proporcionalmente relacionada à idade e ao gênero. Para cumprir o desafio, se apresenta ao grupo dois potes diferentes, sendo que um representa o gênero masculino, outro, o gênero feminino, com faixas-etárias representadas por 0-4, 5-9, 1014. Conjuntamente, os integrantes do grupo recebem tampinhas de garrafa que representam a porcentagem. O valor das tampinhas pode variar dependendo dos dados de cada pirâmide, podendo ser 2, 5 ou 10 milhões para cada tampinha. O grupo deve colocar a quantidade de tampinhas que representam os dados de cada idade e gênero dentro do pote. Resolvendo esse desafio, pode avançar duas casas, até finalizar o jogo.

A Equipe 2 elaborou a atividade Caixas Cartográficas, de acordo com a Figura 3. Essa prática destina-se aos/às estudantes do sexto ano do ensino fundamental e foi pensada com o propósito de trabalhar com jogo de tabuleiro para explorar a cartografia escolar, atendendo às especificidades dos estudantes com deficiência auditiva, para que esses consigam participar do processo ensino-aprendizagem juntamente com os demais colegas. Essa proposta foi pensada à luz da identificação dos sinais de Libras, tendo em vista não só facilitar o meio de comunicação do/a estudante surdo(a), mas, também, explorar a Língua Brasileira de Sinais com os demais membros do grupo.

Figura 3 - Caixas Cartográficas

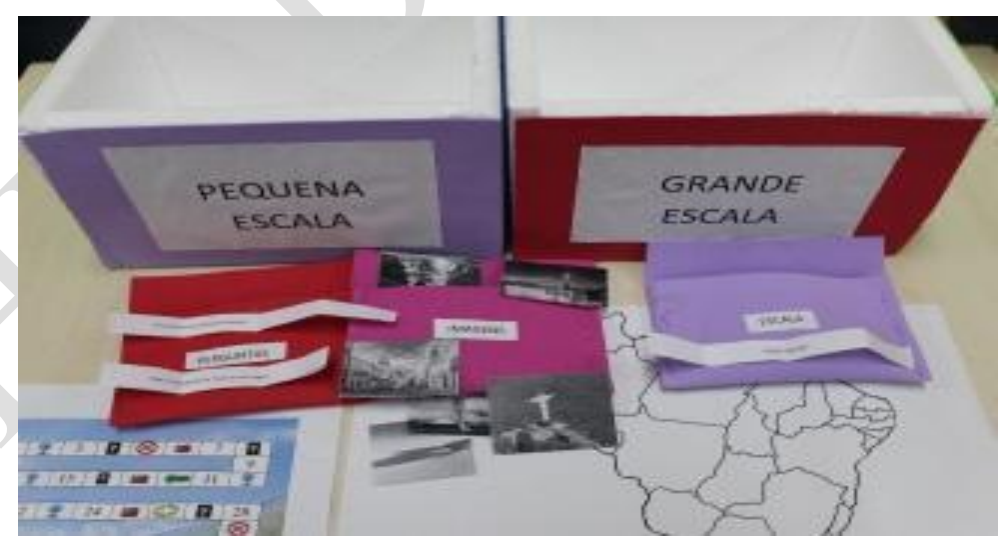

Fonte: Acadêmicos da Licenciatura em Geografia (2019).

Os materiais utilizados foram: duas caixas de isopor, papel craft, canetão, imagens diversas e E.V.A. Para a execução da prática, a turma foi dividida por ordem alfabética pelos professores em quatro equipes de cinco componentes. Cada equipe foi nomeada por cor (Equipe Roxa, Vermelha, Azul e Verde). Após a divisão das equipes, as regras e as atividades foram 
apresentadas, para na sequência, as equipes se organizarem ao redor do tabuleiro e iniciarem o jogo.

O jogo funcionou da seguinte forma: Com o tabuleiro feito em grande escala no chão da sala, um jogador de cada equipe foi escolhido para ser o peão. Esse jogador deveria ser trocado a cada final de rodada, para assim haver oportunidade de todos jogarem e participarem da atividade. Cada equipe teve o direito de jogar o dado que compunha o tabuleiro uma vez por rodada. O jogador percorreria as casas do tabuleiro de acordo com o número do dado (ex: se o dado cair no número 2, a equipe andará duas casas), tendo que realizar a atividade proposta dependendo da casa em que cair, sendo possíveis sete situações.

Quando cair em uma casa com número, nada acontecerá; quando cair na imagem com o globo, terá que fazer a atividade de "Escala". Na casa com a imagem de um ponto de interrogação, será feita a atividade das "Perguntas". Caso caia na imagem com sinal de PARE, a pessoa deve parar. Nas casas com uma câmera fotográfica será feita a atividade com as "Imagens". Nas casas com setas verdes deverá ir para casa seguinte. Na casa com as setas amarelas, indicando retorno, a equipe deverá retornar uma casa. Em caso de acerto da atividade proposta, o peão andará uma casa e terminará sua rodada. Em caso de erro, o peão não se move e finaliza sua rodada. Ganha o jogo quem chegar primeiro à linha de chegada.

A primeira atividade contou com duas caixas para trabalharmos o conceito de "Escala". Foram colocadas duas caixas sobre a mesa com os rótulos de grande e pequena escala respectivamente. $\mathrm{O}$ estudante deveria retirar dois papéis de um envelope e identificá-los e colocá-los na caixa de acordo com a escala referida. A segunda atividade consistiu em perguntas sobre a cartografia escolar, os elementos do mapa e suas funções. O/A estudante deveria retirar a pergunta do envelope, ler em voz alta para turma e, junto com a equipe, respondê-la. A terceira atividade correspondia ao uso das imagens no ensino da cartografia escolar, onde o estudante retirava do enyelope imagens correspondentes a pontos turísticos do território brasileiro. Após, o/a estudante deveria localizar a imagem no mapa do Brasil em relação ao seu Estado.

A terceira atividade aqui descrita foi elaborada pela Equipe 3 e consiste na estrutura da terra tátil. O "Jogóide 8 : viagem ao centro da terra", conforme se vê na Figura 4, foi pensado

\footnotetext{
${ }^{8}$ A tradução da palavra refere-se à junção do conceito de jogo com o significado do formato da terra na linguagem da Geografia Física: Geóide.
} 


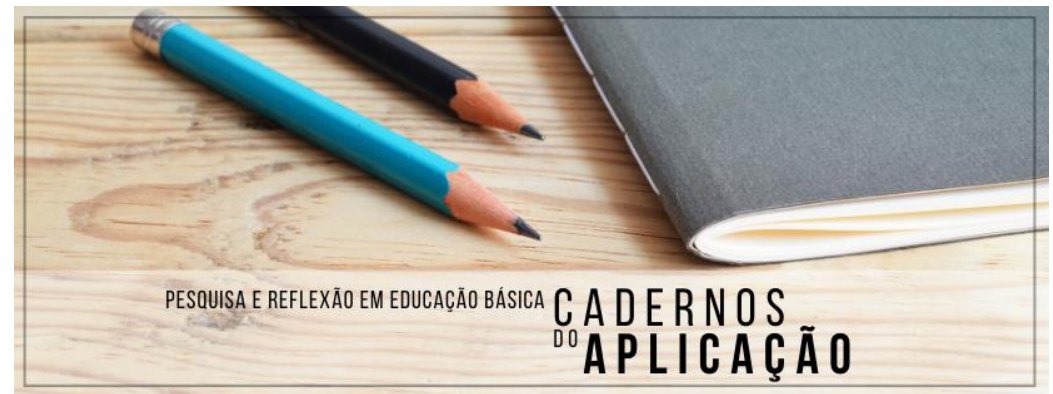

Cadernos do Aplicação

https://seer.ufrgs.br/CadernosdoAplicacao

Publicação Ahead of Print

ISSN 2595-4377 (online)

Porto Alegre | jul-dez. 2021 | v.34 | n.2

para uma turma de sexto ano. A unidade temática sorteada foi a formação do Planeta Terra, com proposta inclusiva para a deficiência auditiva. $\mathrm{O}$ objetivo geral consiste em compreender que a Terra é formada por camadas com características próprias, tendo como objetivos específicos: "conhecer as camadas da terra, da mais externa a mais interna"; "identificar as especificidades das camadas da terra"; e "compreender em escala reduzida a forma da terra". Os conteúdos envolvidos nessa atividade foram "clima, tempo, vulcanismo, placas tectônicas, oceanos e elementos químicos do interior da terra".

Figura 4 - Jogóide: viagem ao centro da terra

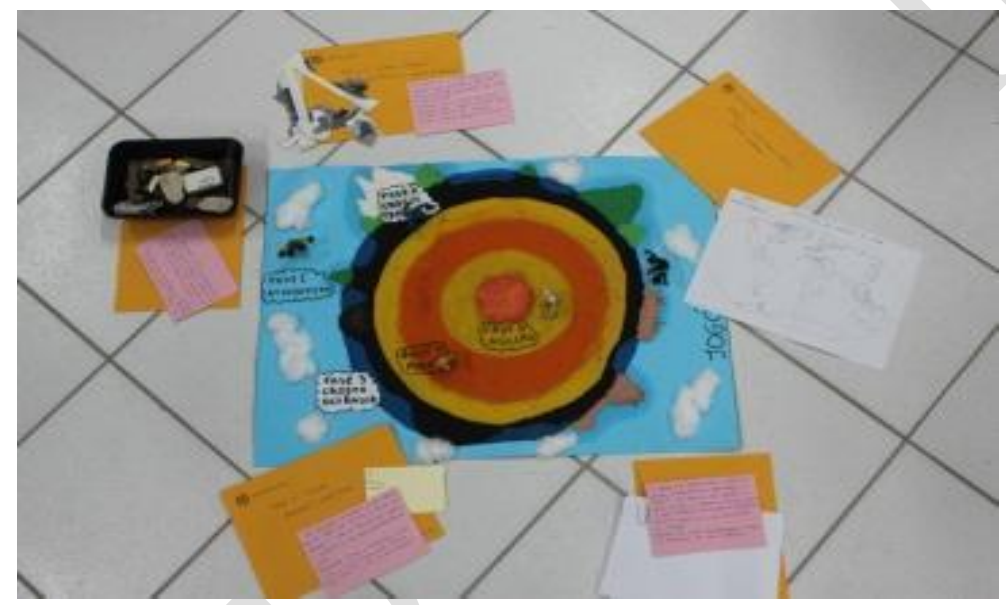

Fonte: Acadêmicos da Licenciatura em Geografia (2019).

Os materiais necessários para elaboração desse jogo foram: tabuleiro das camadas da Terra, avatares para o tabuleiro, livro didático para consulta, envelopes com as atividades de cada fase do jogo, relógio para cronometrar as atividades, folhas de respostas, mapa mundi em branco, quebra-cabeças das placas tectônicas, lápis de cor, objetos de diferentes composições materiais (clips, moedas, lápis, areia, etc.).

Proposta do jogo: a proposta consiste em chegar o mais perto possível do núcleo da Terra, vencendo as 5 fases. O jogo "Jogóide: viagem ao centro da Terra” foi construído levando em consideração a deficiência auditiva de parte dos jogadores. Dessa forma, no jogo, em nenhum momento se vence usando a fala ou respondendo primeiro. Nesse jogo há etapas que envolvem atividades que exploram a cultura visual e escrita, por meio de imagens, objetos, produção de texto, quebra-cabeças, entre outros. 
Para jogar é preciso dividir a turma em grupos de 4 a 6 jogadores. Cada grupo recebe um avatar que indica seu posicionamento no tabuleiro. Há 5 fases no tabuleiro que correspondem a: "Atmosfera, Crosta Terrestre, Crosta Oceânica, Manto e Núcleo". Todos os grupos jogam ao mesmo tempo, tentando cumprir as mesmas tarefas de cada fase. Os grupos que cumprem a tarefa andam uma casa em direção ao núcleo da Terra. O grupo que mais se aproximar do núcleo é o vencedor. Ainda, com esse jogo, não se instiga a competitividade do responder primeiro ou ser mais ágil. Paciência, foco e entrosamento do grupo são primordiais e todos que completarem a atividade ganham pontos para andar rumo ao centro da Terra.

A cada fase o/a professor/a deve fazer uma breve explicação sobre a camada da Terra a que se refere, muitas vezes relacionando com outros conteúdos (oceanos, clima etc.). As tarefas das fases são as seguintes: $1^{\text {a }}$ fase - "Atmosfera: Redigir resposta às perguntas: qual a diferença entre clima e tempo? Como está o tempo hoje? Qual é o clima de Florianópolis?” Para essa atividade foi disponibilizado o cartão no qual as perguntas estavam escritas, uma folha para se escrever a resposta, e o tempo foi cronometrado, sendo cinco (5) minutos para a entrega da resposta.

$2^{\text {a }}$ fase - "Crosta (terrestre): Montar quebra-cabeças das placas tectônicas." Em 3 minutos os participantes deviam ordenar o quebra-cabeça do mapa mundi das placas tectônicas. $3^{\mathrm{a}}$ fase - "Crosta (oceânica): Identificar, escrevendo no mapa em branco, os cinco (5) oceanos da Terra". Tempo para execução: 5 minutos. 4 a fase - "Manto: Desenhar um modelo de vulcão mostrando de onde vem o magma do manto emergindo em lava na superfície." Tempo: 15 minutos; e a $5^{\text {a }}$ fase - "Núcleo: Dentre os objetos apresentados, escolher aqueles que podem apresentar os elementos químicos do núcleo da Terra (ferro e níquel)". Os/as estudantes deveriam descobrir quais são esses dois elementos e, em seguida, escolher entre os objetos quais deles representam o material do núcleo terrestre. As opções podiam ser: moedas, lápis de madeira, papel, borracha, régua, clipes, etc. Tempo: 5 minutos.

Ao final dessa última fase, o jogo termina. O grupo que mais se aproximar do centro da Terra será o vencedor do "Jogóide: viagem ao centro da Terra". Mas o aprendizado não precisa acabar aí. Dúvidas podem surgir quanto ao conteúdo abordado e é possível também comparar respostas dos grupos e corrigi-las. Finda a etapa de socialização dos planos de aula e as 
atividades elaboradas pelos acadêmicos, os mesmos foram convidados a compartilhar o que perceberam dessa prática e como ela contribui para sua formação.

\section{Reflexões finais}

Este artigo é fruto de reflexões e diálogos sobre a educação inclusiva, fundamentados em princípios que buscam romper com ideias e verdades consideradas absolutas, bem como com os preconceitos. Nos pautamos em referenciais que possibilitam compreender cada indivíduo a partir da sua subjetividade e do espaço que está inserido.

A perspectiva e contribuições teóricas de Hall (1997) permitem a associação do conceito de diferença ao conceito de cultura, ou seja, cada sujeito se desenvolve pertencendo a uma rede de práticas culturais, predispostas ao habitus. ao mesmo tempo em que todo sujeito exerce agência na estrutura social. O desenvolvimento e a forma de ser estão ligados à estrutura social e ao contexto em que cada um se insere e a forma com que atua no mundo. $\mathrm{O}$ reconhecimento da diferença biológica perpassa os modos de ser, pensar, agir, sentir, ou seja, perpassa a esfera cultural, pois envolve também a estrutura de personalidade de cada indivíduo. Nesse sentido, o reconhecimento da diferença social é produzido pela própria rede cultural, portanto, envolta numa teia relacional, onde há tanto coalizões de forças centrípetas e centrífugas, como também modos de ser, agir, sentir e pensar que já estavam em circulação no modo de vida global muito antes de nossa chegada em dado tempo e espaço.

Afirma-se, neste trabalho, que a diferença é parte inseparável e indelével da existência humana. A cultura, entretanto, reflete e até produz os modos de ação e reação com o outro, que é diferente. A escola, como micro espaço social, tem a potencialidade de desenvolver processos educativos e práticas inclusivas que promovam aos/às estudantes e docentes tempos e espaços para conviver com o outro, com a pluralidade de ideias e concepções pedagógicas, problematizando as desigualdades que assolam nosso país e buscando construir relações que ofereçam condições estruturais para acolher todos/as, assim como também criticar as injustiças sociais a que temos nos submetido em nosso ainda recente processo brasileiro de redemocratização. . 


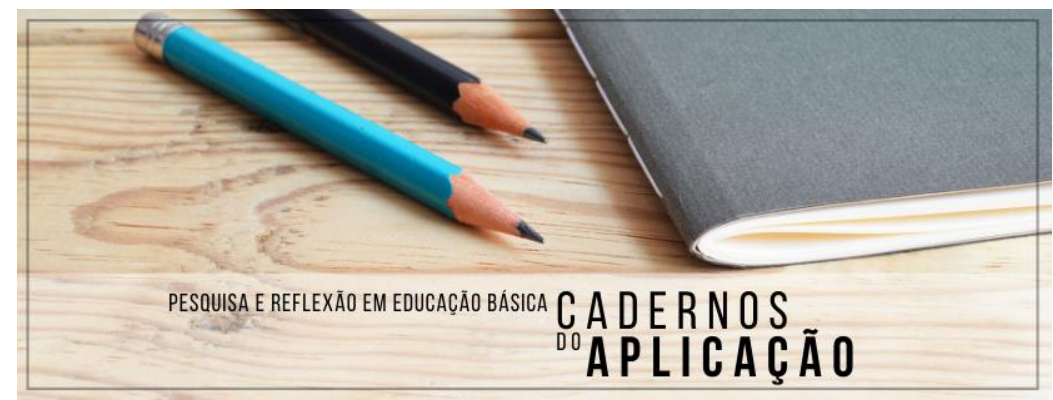

Cadernos do Aplicação

https://seer.ufrgs.br/CadernosdoAplicacao

Publicação Ahead of Print

ISSN 2595-4377 (online)

Porto Alegre | jul-dez. 2021 | v.34 | n.2

A construção de um projeto educacional se constitui assentada na valorização e no acolhimento de diferentes valores, particularidades, características, capacidades e subjetividades no espaço educativo. A inclusão provoca aprimoramento, movimento e ressignificação das manifestações culturais vividas na escola. A educação inclusiva é uma grande oportunidade para que a escola seja repensada em algumas de suas práticas, atendendo às exigências de uma sociedade que vem buscando em diferentes níveis a superação de preconceitos e discriminações, barreiras entre indivíduos, povos e culturas. Partindo do princípio de que "[...] a proposta de inclusão enfatiza a igualdade concreta entre os indiyíduos, com o reconhecimento das diferenças [...]" (LIMA, 2006, p. 21), a efetivação de um trabalho inclusivo põe em jogo um conjunto de elementos articulados e integrados entre si: a esfera da política educacional, da formação de professores/as, a relação com as famílias e a consolidação de um trabalho caracterizado pela intersetorialidade. Com base nessa reflexão, Gallo (2005), destaca que é fundamental trabalhar na escola no sentido de educar para a diferença.

Neste sentido, nosso objetivo com a proposta de organização de materiais e atividades pedagógicas numa perspectiva inclusiva, foi o de romper com uma hegemonia que predomina nos espaços escolares, onde a diferença, muitas vezes, é silenciada ou apagada. Acreditamos que a proposta desenvolvida com a turma demonstrou potencial rico de atuação, integração e aprendizagem do conteúdo com e para os/as estudantes que serão professores/as da educação básica.

Desde então, as palavras de Amaro (2017), vem ao encontro do que defendemos e acreditamos que (re) inventar o dia a dia na sala de aula com práticas diferenciadas permite verdadeiramente que todos os/as estudantes aprendam de algum modo os conhecimentos curriculares. Além disso, práticas pensadas a partir de quem são e como são os/as estudantes, possibilitam a revisão e reelaboração de propostas pedagógicas convencionais e segregadoras que elevam a exclusão dos/as estudantes no processo educativo.

\section{Referências}

AMARO, Deigles Giacomelli. Práticas pedagógicas articuladas para o desenvolvimento e o aprendizado dos alunos. In: GALERY, A. et al. (Orgs.) A escola para todos e para cada um. São Paulo: Summus, 2017. 


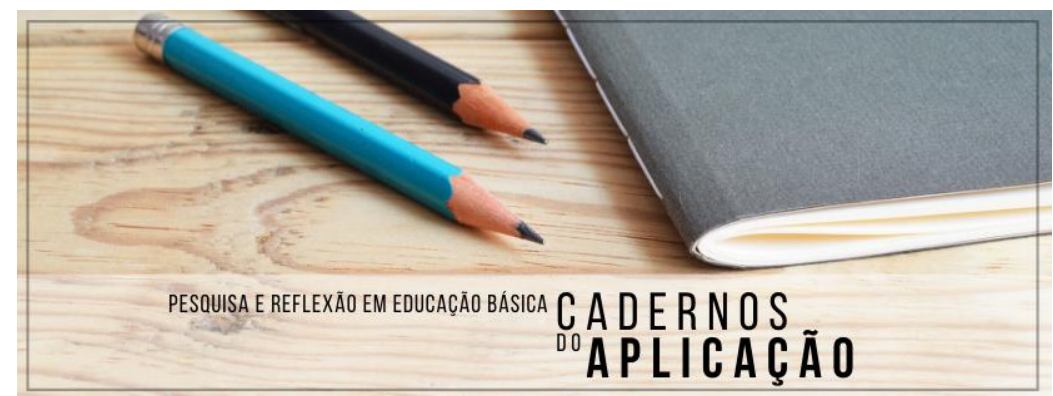

Cadernos do Aplicação https://seer.ufrgs.br/CadernosdoAplicacao

Publicação Ahead of Print

ISSN 2595-4377 (online)

Porto Alegre | jul-dez. 2021 | v.34 | n.2

BATISTA, Maria Valdeli Matias. Saberes culturais de jovens e adultos com deficiência de comunidades das ilhas de Abaetetuba-PA. Dissertação (Mestrado em Educação). Programa de Pós-Graduação em Educação. Universidade Federal do Pará, 2016.

BOFF, Leonardo. A águia e a galinha. Edição comemorativa 20 anos, 2017.

CAMACHO, Orlando Terré. Atenção à diversidade e educação especial. Porto Alegre: EDIPUCRS, 2003.

COSTA, Marisa Vorraber; WORTMANN, Maria Lucia; BONIN, Iara Tatiana. Contribuições dos estudos culturais às pesquisas sobre currículo - uma revisão. Currículo sem Fronteiras, v. 16, n. 3, p. 509-541, set./dez. 2016.

DALMONTE, Edson Fernando. A cultura popular a partir dos estudos culturais britânicos. Infoamérica - Revista Iberoamericana de Comunicación, São Paulo, v. 1, n. 2, p. 1-15, out./nov. 2001.

ESCOSTEGUY, Ana Carolina. Os estudos culturais. In: HOHLFELDT, Antonio; MARTINO, Luiz Claudio; FRANÇA, Vera Veiga. (Orgs.). Teorias da comunicação- conceitos, escolas e tendências. 6. ed. Petrópolis: Vozes, 2006, p. 151-170.

ESCOSTEGUY, Ana Carolina. Uma introdução aos estudos culturais. Revista Famecos, Porto Alegre, v. 5, n. 9, p. 87-97, set./dez. 1998.

FREIRE, Paulo. Pedagogia do Oprimido. Rio de Janeiro: Paz e Terra, 1987.

GALLO, Silvio Donizetti de Oliveira. Sob o signo da diferença: em torno de uma educação para a singularidade. In: SILVEIRA, Rosa Maria Hessel. (Org.). Cultura, poder e educação um debate sobre estudos culturais em educação. Canoas/RS: Editora da ULBRA, v. 2, n.1, p. 213-223, set./out. 2005.

HALL, Stuart. The centrality of culture: notes on the cultural revolutions of our time. In: THOMPSON, Kenneth (ed.). Media and cultural regulation. London, Thousand Oaks, New Delhi: The Open University; SAGE Publications, 1997.

KAERCHER, Nestor. André. Fugir do tédio e do denuncismo: mestres com fome e em busca de ensino e aprendizagem significativas. In: CASTROGIOVANNI, Antonio Carlos et al. (Orgs.) Movimentos para ensinar geografia-oscilações. Porto Alegre: Editora Letra 1, 2016.

LIMA, Priscila Augusta. Educação inclusiva e igualdade social. São Paulo, Avercamp, 2006.

LOPES, Maria Coracini; FABRIS, Eli Henn. Inclusão e educação. 1 ed.; 1.reimp. Belo Horizonte: Autêntica Editora, 2016.

ORRÚ, Silva Ester. O re-inventar da inclusão: os desafios da diferença no processo de ensinar e aprender. Petrópolis, Rio de Janeiro: Vozes, 2017. 


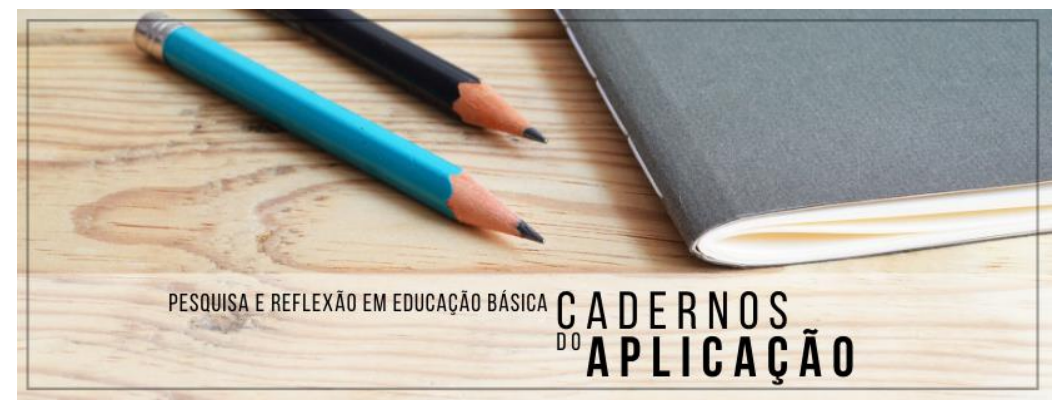

Cadernos do Aplicação https://seer.ufrgs.br/CadernosdoAplicacao

Publicação Ahead of Print ISSN 2595-4377 (online)

Porto Alegre | jul-dez. 2021 | v.34 | n.2

MARQUES, Carlos Alberto; MARQUES, Luciana Pacheco. Do universal ao múltiplo: os caminhos da inclusão. In: LISITA, Verbana Moreira, SOUSA, Luciana Freire (Orgs.). Práticas educacionais, práticas escolares e alternativas de inclusão escolar. Rio de Janeiro: DPA, 2003. p. 234.

MORIN, Edgar. Os sete saberes necessários à educação do futuro. 2. ed. rev. São Paulo: Cortez, 2011.

NICODEM, Maria Fatima Menegazzo. A inserção de Paulo Freire nos estudos culturais: o conceito de cultura nas pedagogias do oprimido, da esperança e da autonomia. Revista Eletrônica Científica Inovação e Tecnologia, Paraná, v. 6, n.13, p. 23-33, set./agost. 2015.

SILVA, Aida Maria Monteiro et al. Educação inclusiva e direitos humanos: perspectivas contemporâneas. São Paulo: Cortez, 2015.

SILVA, Tomaz Tadeu da. A produção social da identidade e da diferença. In: SILVA, Tomaz Tadeu da (Org.). Identidade e diferença: a perspectiva dos estudos culturais. Petrópolis: Vozes, 2000 .

VEIGA-NETO, Alfredo. Nietzche e Wittgenstein: alavancas para pensar a diferença e a Pedagogia. In: GALLO, Silvio; SOUZA, Regina Maria. (Org.). Educação do preconceito ensaios sobre poder e resistência. Campinas: Alínea, 2004.

VEIGA-NETO, Alfredo, LOPES, Maura Coracini. Inclusão, exclusão, in/inclusão. Revista Verve, v. 20, n. 1, p.121-135, set./nov. 2011.

VYGOTSKY, Lev Semyonovich. Formação social da mente. 6. ed. São Paulo: Martins Fontes, 1998, p. 97-110.

WORTMANN, Maria Lucia Castagna; COSTA, Marisa Vorraber; SILVEIRA, Rosa Maria Hessel. Sobre a emergência e a expansão dos estudos culturais em educação no Brasil. Revista Educação, Porto Alegre, v. 38, n. 1, p. 32-48, jan./abr. 2015.

YIN, Robert K. Estudo de caso: planejamento e métodos. Tradução de Daniel Grassi. 3. ed. Porto Alegre: Bookman, 2004, p.23.

Data de submissão: 13/03/2021

Data de aceite: $30 / 05 / 2021$

DOI: https://doi.org/10.22456/2595-4377.112110 